(СВ. О. Орловський ${ }^{1}$ М. М. Шінкарук-Диковицька ${ }^{1}$, І. В. Гунас ${ }^{2}$

Вінницький національний медичний університет імені М. І. Пирогова ${ }^{1}$ Міжнародна академія інтегративної антропології, м. Вінниця²

\title{
МОДЕЛЮВАННЯ ЗА ДОПОМОГОЮ РЕГРЕСІЙНОГО АНАЛІЗУ ІНДИВІДУАЛЬНИХ ЛІНІЙНИХ РОЗМІРІВ МАЛИХ КУТНІХ ЗУБІВ ЗАЛЕЖНО ВІД КЕФАЛОМЕТРИЧНИХ ПОКАЗНИКІВ ПРАКТИЧНО ЗДОРОВИХ ЧОЛОВІКІВ ІЗ РІЗНИХ РЕГІОНІВ УКРАЇНИ
}

\begin{abstract}
Резюме. Згідно з літературними даними, розробка різноманітних діагностичних моделей повинна бути адаптована до населення конкретного регіону.

Мета дослідження - побудувати і провести аналіз регресійних моделей індивідуальних лінійних розмірів малих кутніх зубів залежно від кесралометричних показників практично здорових чоловіків із різних адміністративно-територіальних регіонів України. Матеріали і методи. Проведено комп'ютерно-томографрічне дослідження малих кутніх зубів із наступними одонтометрією i кесралометрією. 200 практично здоровим чоловікам-мешканцям різних адміністративно-територіальних регіонів України (північний регіон - 32 мешканці з Житомирської, Київської, Чернігівської та Сумської областей; південний регіон - 33 мешканці 3 Одеської, Миколаївської, Херсонської, Запорізької областей та АР Крим; центральний регіон - 64 мешканці з Вінницької, Черкаської, Кіровоградської, Полтавської та Дніпропетровської областей; західний регіон - 36 мешканців із Волинської, Рівненської, Львівської, Чернівецької, Тернопільської, Хмельницької, Закарпатської та Івано-Франківської областей; східний регіон - 35 мешканців із Харківської, Донецької та Луганської областей). Побудову регресійних моделей індивідуальних лінійних розмірів малих кутніх зубів залежно від кефалометричних показників, проводили за допомогою ліцензійного статистичного програмного пакета Statistica 6.1.

Результати досліджень та їх обговорення. За допомогою регресійного аналізу на основі особливостей кесралометричних показників, краніотипу і типу обличчя ми побудували достовірні моделі (із коефріцієнтом детермінації $\mathrm{R}^{2}$ більшим ніж 0,5 ) індивідуальних лінійних розмірів малих кутніх зубів верхньої і нижньої щелеп у практично здорових чоловіків північного, південного, західного і східного адміністративно-територіальних регіонів України. У більшості випадків, незалежно від регіону, моделі мезіо-дистальних розмірів коронки і шийки малих кутніх зубів побудовані для верхньої, а висоти коронок - для нижньої щелепи. До побудованих моделей індивідуальних лінійних розмірів малих кутніх зубів верхньої і нижньої щелеп із коефріцієнтом детермінації більше 0,5 найчастіше входять: у чоловіків північного регіону України до моделей мезіо-дистальних розмірів поперечна дуга і ширина ротової щілини (по 10,5 \%) та ширина основи носа, ширина нижньої щелепи і довжина тіла нижньої щелепи зліва (по 7,9 \%); до моделей присінково-язикових розмірів - висота верхньої частини обличчя (16,0 \%), найбільша довжина голови, довжина тіла нижньої щелепи зліва і морфологічна довжина обличчя (по 12,0%); до моделей висоти коронок - зовнішньоочна ширина (18,7 \%) та поперечна дуга і довжина тіла нижньої щелепи зліва (по 12,5 \%); у чоловіків південного регіону України до моделей висоти коронок - висота лоба (17,6 \%), найбільший обхват голови, ширина основи носа, міжочноямкова ширина і довжина тіла нижньої щелепи справа (по 11,8 \%); у чоловіків західного регіону України до моделей мезіодистальних розмірів - найбільший обхват голови і відстань між назіон та міжрізцевою точкою (по 14,8 \%), поперечна дуга, ширина ротової щілини і довжина тіла нижньої щелепи справа (по 11,1 \%); у чоловіків східного регіону України до моделей мезіо-дистальних розмірів - сагітальна дуга, ширина ротової щілини і висота лоба (по 12,8 \%), середня ширина обличчя (10,3 \%) і довжина тіла нижньої щелепи зліва (7,7 \%); до моделей присінково-язикових розмірів - поперечна дуга, ширина ротової щілини, зовнішньоочна ширина, ширина нижньої щелепи і довжина носа (по 14,3%).

Висновки. На основі особливостей кефалометричних показників та типу голови й обличчя у практично здорових чоловіків із різних адміністративно-територіальних регіонів України розроблені достовірні регресійні моделі індивідуальних лінійних розмірів малих кутніх зубів верхньої і нижньої щелеп.
\end{abstract}

Ключові слова: малі кутні зуби; лінійні розміри; кесралометрія; регресійні моделі; практично здорові чоловіки; адміністративно-територіальні регіони України.

ВСтуп На даний час відомі три варіанти прогнозування розмірів зубів: використання табличних даних середніх значень зубів [10]; застосування регресійних рівнянь, що базуються на взаємозв'язках між розмірами зубів і розмірами щелеп і зубних дуг [3]; аналіз інфрормації, яку одержують при вивченні площинних рентгенівських зображень у комбінації із використанням регресійних рівнянь $[2,8]$. Кожна зі згаданих груп методів має ряд недоліків, основним 3 яких $є$ неточність отриманих результатів, що зумовлено такими фракторами: відсутність урахування індивідуальних особливостей анатомії зубів при орієнтації на дані про середні табличні величини їх розмірів; відсутність універсального характеру регресійних рівнянь, які застосовують, унаслідок наявності статевих, вікових, расових і етнічних відмінностей у розмірах і анатомії зубів; неможливість прогнозу розмірів зубів на підставі регресійного рівняння при відсутності кефалометричних показників; спотворення справжніх розмірів зубів, величина яких варіює залежно від виду й ділянки рентгенографічного дослідження [2, 9].
На сьогодні все частіше обговорюють можливість помилок при застосуванні регресійного аналізу, зважаючи на расово-популяційні варіації розмірів зубів і краніосрасціального комплексу. Тому в даний час, виходячи з етнотериторіальних варіацій морсоологічних параметрів, розробляють діагностичні моделі, адаптовані до населення конкретного регіону [7].

Метою дослідження було побудувати і провести аналіз регресійних моделей індивідуальних лінійних розмірів малих кутніх зубів залежно від кефралометричних показників практично здорових чоловіків із різних адміністративно-територіальних регіонів України.

МАТЕРІАЛИ І МЕТОДИ У резУльтаті попереднього опитування, яке провів колектив науковців (за допомогою скринінг-опитувальника [6] більше ніж 3500 чоловіків віком від 19 до 35 років із різних регіонів України), було відібрано 200 практично здорових, мешканців різних адміністративно-територіальних регіонів у третьому поколінні зі сприйнятливими, помірно сприйнятливими і задовільними екологічними умовами проживання, згідно з дослі- 
дженнями Національного екологічного центру України: північний регіон - 32 мешканці з Житомирської, Київської, Чернігівської та Сумської областей; південний регіон - 33 мешканці з Одеської, Миколаївської, Херсонської, Запорізької областей та АР Крим; центральний регіон - 64 мешканці з Вінницької, Черкаської, Кіровоградської, Полтавської та Дніпропетровської областей; західний регіон - 36 мешканців із Волинської, Рівненської, Львівської, Чернівецької, Тернопільської, Хмельницької, Закарпатської та Івано-Франківської областей; східний регіон - 35 мешканців із Харківської, Донецької та Луганської областей). Усім їм провели кефалометричне (на базі кафредри стоматології дитячого віку і науково-дослідного центру Вінницького національного медичного університету імені М. І. Пирогова) і комп'ютерно-томограсрічне (на базі приватної стоматологічної клініки "Вінінтермед ЛТД") дослідження.

Конусно-променеву комп'ютерну томограсрію виконали за допомогою дентального конусно-променевого томографра Veraviewepocs-3D (Morita, Японія). Об'єм тривимірного зображення - циліндр 8х8 см, товщина шару - 0,2/0,125 мм, доза опромінення - 0,011-0,048 м3в, напруга та сила струму - 60-90kV/2-10mA. Дослідження тривимірної моделі кісткових структур зубощелепного комплексу проводили в програмній оболонці i-Dixel One Volume Viewer (Ver.1.5.0, J Morita Mfg. Cor.). На конуснопроменевих комп'ютерних томограмах малих кутніх зубів верхньої й нижньої щелеп вимірювали: довжини зуба; піднебінного і щічного коренів малих кутніх зубів верхньої й нижньої щелеп; висоти коронки зуба; присінково-язикових розмірів коронки і шийки зуба; мезіо-дистальні розміри коронки і шийки зуба [5].

Кефралометричне дослідження складалося з визначення параметрів мозкового та лицьового відділів голови, за допомого великого ковзного циркуля із шкалою у натуральну величину системи Мартіна та м'якої сантиметрової стрічки. А також із урахуванням загальноприйнятих рекомендацій та анатомічних точок [1].

Форму голови визначали за наступною фрормулою [4]: найбільша ширина голови/найбільша довжина голови×100. При значенні до 75,9 чоловіки належали до доліхоцефалів; 76,0-80,9 - до мезоцефралів; 81,0-85,4 - до брахіцесралів; 85,5 і більше - до гіпербрахіцефалів.

Значення лицевого вказівника (морфологічного індексу Гарсона) отримували за відповідною формулою [5]: морфологічна довжина обличчя/найбільша ширина обличчя×100. При значенні показника до 78,9 чоловіки належали до групи з дуже широким обличчям; 79,0-83,9 - широким обличчям; 84,0-87,9 - середнім обличчям; 88,0-92,9 - вузьким обличчям; 93,0 і більше - дуже вузьким обличчям.

Побудову регресійних моделей індивідуальних лінійних розмірів малих кутніх зубів, залежно від кефралометричних показників, проводили за допомогою ліцензійного статистичного програмного пакета Statistica 6.1.

РЕЗУЛЬТАТИ ДОСЛІДЖЕНЬ ТА ЇХ ОБГОВОРЕННЯ Побудовані регресійні моделі комп'ютерно-томографічних лінійних розмірів малих кутніх зубів, залежно від особливостей кефалометричних показників, краніотипу і типу обличчя практично здорових чоловіків із різних регіонів України, мають вигляд наступних лінійних рівнянь:

- мезіо-дистальний розмір коронки верхнього правого другого малого кутнього зуба (північний регіон) =

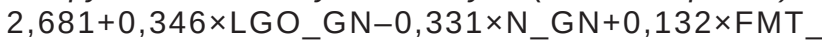

FMT+0,175×GO_GO+0,193×CHI_CHI (коефріцієнт детермінації $\mathrm{R}^{2}=0,578 ; \mathrm{F}_{(5,26)}=7,13 ; \mathrm{p}<0,001$; Error of estimate $=0,262)$;

- присінково-язиковий розмір шийки верхнього правого першого малого кутнього зуба (північний регіон) = $-11,36+0,536 \times$ N_STO-0,356 $\times$ G_OP $+1,518 \times$ LGO $\mathrm{GN}+0,972 \times N \_G N-0,270 \times Z Y \_Z Y+0,125 \times N \_P R N\left(R^{2}=0,643\right.$; $F_{(5,26)}=7,13 ; p<0,001$; Error of estimate $\left.=0,6 \overline{3} 2\right)$;

- присінково-язиковий розмір коронки верхнього правого першого малого кутнього зуба (північний регіон) $=-3,611+0,640 \times N$ STO $+1,086 \times$ LGO_GN - 0,254 $\times$ G $\mathrm{OP}+0,614 \times \mathrm{N} \_\mathrm{GN}-0,197 \times \mathrm{FMT} F M T\left(\mathrm{R}^{2}=0,525 ; \mathrm{F}_{(5,26)}=5,7 \overline{\text {; }}\right.$ $\mathrm{p}<0,01$; Error of estimate $=0,60 \overline{5})$;

- висота коронки верхнього правого першого малого кутнього зуба (північний регіон) $=5,858+0,375 \times E U$ $\mathrm{EU}+0,513 \times \mathrm{EK} \mathrm{EK}+1,965 \times \mathrm{LGO} \mathrm{GN}-1,877 \times \mathrm{RGO}$ GN$0,285 \times$ DUG_AUAU-0,586 $\times$ N_GN+0,195 $\times$ DUGS_GOP $\left(R^{2}=0,632 ; F_{(5,88)}^{-}=7,24 ; p<0,001 ;\right.$ Error of estimate $\left.=0, \overline{5} 74\right)$;

- мезіо-дистальний розмір шийки верхнього правого першого малого кутнього зуба (північний регіон) =

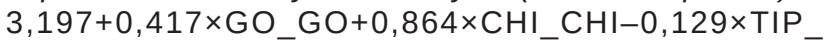
$\mathrm{LICA}+0,228 \times \mathrm{EU} E \mathrm{E}-0,182 \times \mathrm{DUG}$

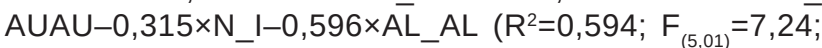
$\mathrm{p}<0,01$; Error of estimate $=0,353)$;

- присінково-язиковий розмір шийки верхнього лівого першого малого кутнього зуба (північний регіон) =

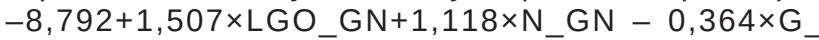

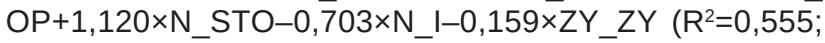
$F_{(5,19)}=6,25 ; p<0,01 ;$ Error of estimate $\left.=0,73 \overline{1}\right)$;

- мезіо-дистальний розмір шийки верхнього лівого першого малого кутнього зуба (північний регіон) = $4,030+0,912 \times$ CHI_CHI+0,311 $\times$ GO_GO-0,179 $\times$ DUG_

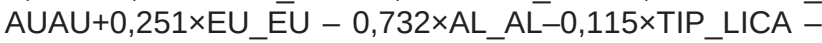
$0,303 \times N_{-}$I $\left(R^{2}=\overline{0}, 562 ; F_{(4,40)}=5,24 ; p<0,01 ;\right.$ Error of estimate $=0,358)$;

- мезіо-дистальний розмір коронки другого верхнього лівого другого малого кутнього зуба (північний регіOH) $=7,187+0,341 \times$ LGO_GN-0,433 $\times$ N_GN-0,815 $\times$ AL $A L+0,107 \times$ DUGS_GOP $+0,158 \times E K \_E K-0,114 \times T R \_\bar{N}$ $\left(R^{2}=0,604 ; F_{(6,25)}=6,34 ; p<0,001 ;\right.$ Error of estimate $\left.=0,285\right)$;

- присінково-язиковий розмір коронки нижнього лівого другого малого кутнього зуба (північний регіон) =

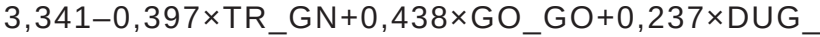

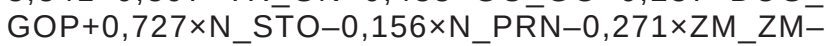
$0,135 \times \mathrm{DUG} A \mathrm{AUAU}+0,283 \times \mathrm{CHI} C \mathrm{CHI}\left(\mathrm{R}^{2}=0,822\right.$; $F_{(8,23)}=13,30 ; p<0,001$; Error of estimate $\left.=0,260\right)$;

- мезіо-дистальний розмір шийки нижнього лівого другого малого кутнього зуба (північний регіон) =

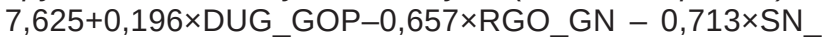

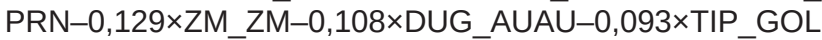
$\left(R^{2}=0,648 ; F_{(6,25)}=7,67 ; p<0,001 ;\right.$ Error of estimate $\left.=0,238\right)$;

- висота коронки нижнього лівого першого малого кутнього зуба (північний регіон) $=-10,37+0,388 \times E K$ $\mathrm{EK}+0,711 \times \mathrm{LGO} \mathrm{GN}+0,280 \times \mathrm{TIP}$ GOL+0,199 $\times$ DUG_AUAU $\left(R^{2}=0,507 ; F_{(4,27)}=6,94 ; p<0,001 ; \bar{E}\right.$ rror of estimate=0,592);

- висота коронки нижнього правого першого малого кутнього зуба (північний регіон) $=-3,372+0,451 \times$ TIP

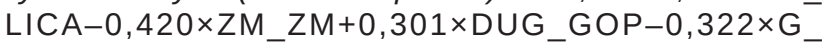
$\mathrm{OP}+0,326 \times E K \_E K\left(\mathrm{R}^{2}=0,596 ; F_{(5,26)}=7, \overline{66} ; \mathrm{p}<0,001\right.$; Error of estimate $=0,563$ );

- мезіо-дистальний розмір шийки нижнього правого другого малого кутнього зуба (північний регіон) =

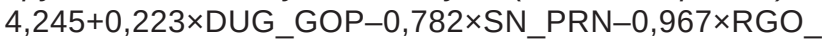

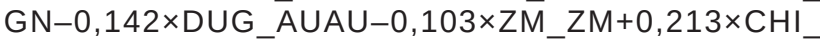


$\mathrm{CHI}+0,444 \times$ LGO_GN $\left(\mathrm{R}^{2}=0,715 ; \mathrm{F}_{(7,24)}=8,61 ; \mathrm{p}<0,001\right.$; Error of estimate $=0,23 \overline{5}$ );

- мезіо-дистальний розмір шийки верхнього лівого другого малого кутнього зуба (південний регіон) =

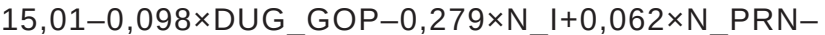
$0,320 \times N$ STO-0,194 $\times$ RGO_GN $\left(R^{2}=0,509 ; F_{(5,27)}=5,60\right.$; $\mathrm{p}<0,01$; Error of estimate $=0,341)$;

- висота коронки нижнього лівого другого малого кутнього зуба (південний регіон) $=16,76-0,099 \times$ DUG_

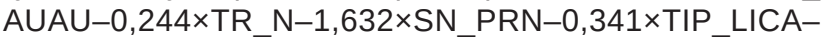
$0,829 \times A L \_A L+0,172 \times Z M \_Z M-\left(R^{2}=0,631 ; F_{(6,26)}=7,41\right.$; $\mathrm{p}<0,001$; Error of estimate $=0,456)$;

- висота коронки нижнього лівого першого малого кутнього зуба (південний регіон) $=22,70-0,440 \times$ DUG_ GOP-0,726 $\times$ MF_MF-0,229 $\times$ TR N $+0,433 \times \mathrm{RGO}$ $\mathrm{GN}+0,448 \times E U \_\mathrm{EU}+0,618 \times A L \_A L\left(R^{2}=0,702 ; F_{(6,26)}=10,1 \overline{9}\right.$; $\mathrm{p}<0,001$; Error of estimate $=0,392)$;

- висота коронки нижнього правого першого малого кутнього зуба (південний регіон) $=25,43-0,290 \times$ DUG_

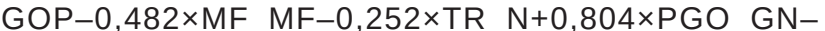
$0,655 \times$ LGO_GN $\left(\bar{R}^{2}=0,564 ; F_{(5,27)}=\overline{6}, 98 ; p<0,001\right.$; Error of estimate $=0,459$ )

- мезіо-дистальний розмір коронки верхнього правого другого малого кутнього зуба (західний регіон) = $2,747+0,389 \times S N \_P R N+0,739 \times N \_I+0,405 \times R G O \_G N-$ $0,216 \times D \cup G$ GOP $+0,116 \times D \cup G \_A \cup A U+0,04 \overline{5} \times N$ $\mathrm{SN}+0,251 \times \mathrm{CHI} C \mathrm{CHI}\left(\mathrm{R}^{2}=0,659 ; \mathrm{F}_{(7,28)}=7,71 ; \mathrm{p}<0,001 ;\right.$ Error of estimate $=0,322)$;

- мезіо-дистальний розмір шийки верхнього правого першого малого кутнього зуба (західний регіон) = $-4,022+0,516 \times \mathrm{G} \quad \mathrm{O} P+0,472 \times \mathrm{R} \mathrm{G} \mathrm{O}$ $\mathrm{GN}+0,335 \times \mathrm{N} \quad \mathrm{I}-0,195 \times \mathrm{DUG}$ GOP $+0,308 \times \mathrm{GO} \quad \mathrm{GO}$ $\left(R^{2}=0,538 ; F_{(5,30)}=6,98 ; p<0,001 ;\right.$ Error of estimate $\left.=0,385\right)$;

- мезіо-дистальний розмір коронки верхнього лівого другого малого кутнього зуба (західний регіон) = $3,601+0,648 \times N \quad I+1,011 \times R G O$ GN $-0,228 \times D U G$ $\mathrm{GOP}+0,174 \times \mathrm{DUG}$ AUAU+0,723 $\times \mathrm{N}$ SN $+0,512 \times \mathrm{CHI} C \mathrm{CHI}-$ $0,786 \times$ LGO_GN-0,654 $\times$ N_PRN $\left(\bar{R}^{2}=0,656 ; F_{(6,43)}=8,27\right.$; $\mathrm{p}<0,001$; Error of estimate $=\overline{0}, 341)$;

- висота коронки нижнього правого першого малого кутнього зуба (західний регіон) =

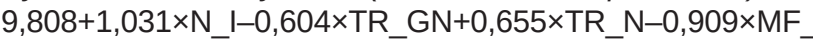
$\mathrm{MF}+0,114 \times \mathrm{ZY} \quad \mathrm{ZY}-0,943 \times \mathrm{LGO} \quad \mathrm{GN}+0,731 \times \mathrm{RGO} \quad \mathrm{GN}$ $\left(R^{2}=0,522 ; F_{(4,37)}=5,28 ; p<0,01 ;\right.$ Error of estimate $\left.=0,533\right)$;

- мезіо-дистальний розмір коронки другого нижнього правого другого малого кутнього зуба (західний регіон) $=1,543+0,428 \times$ SN_PRN+0,239 $\times$ DUG_AUAU+0,439 $\times \mathrm{N}$ STO $+0,652 \times$ CHI_CHI $-0,148 \times$ DUG_GOP-0,088×ZM_ $Z M+0,318 \times N_{-}$I $\left(\bar{R}^{2}=0,535 ; F_{(4,60)}=5,2 \overline{8} ; p<0,01\right.$; Error of estimate $=0,436)$

- мезіо-дистальний розмір коронки верхнього правого другого малого кутнього зуба (східний регіон) =

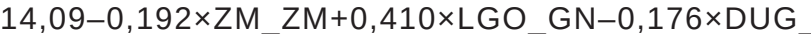
$\mathrm{GOP}+0,648 \times \mathrm{MF}$ MF-0,206 $\times \mathrm{TR}^{-} \mathrm{N}-0,395 \times \mathrm{CHI}^{-}$ $\mathrm{CHI}+0,539 \times A L \_A L\left(\bar{R}^{2}=0,641 ; F_{(6,88)}=7, \overline{27} ; \mathrm{p}<0,001 ;\right.$ Error of estimate $=0,278$ )

- мезіо-дистальний розмір коронки верхнього правого першого малого кутнього зуба (східний регіон) =

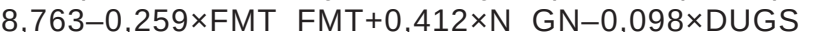

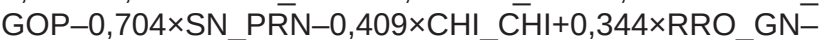
$0,495 \times$ TR_N+0,113 $\times$ TR_GN $\left(\mathrm{R}^{2}=0,630 ; \mathrm{F}_{(5,54)}=8,26\right.$; $\mathrm{p}<0,001$; Error of estimate $=0,390)$;

- мезіо-дистальний розмір коронки верхнього лівого першого малого кутнього зуба (східний регіон) = 10,12-

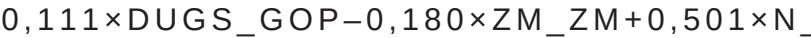

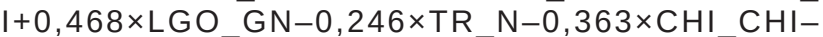
$0,193 \times G$ OP $\left(\bar{R}^{2}=0,594 ; F_{(5,65)}=\overline{7}, 27 ; p<0,001\right.$; Error of estimate $=0,352$ );

- мезіо-дистальний розмір коронки верхнього лівого другого малого кутнього зуба (східний регіон) = 8,621+0,366×LGO GN-0,130×DUGS GOP-0,173×TIP LICA-0,218 $\times$ CHI_CHI $\left(R^{2}=0,527 ; F_{(4,30)}=8,24 ; p<0,001\right.$; Error of estimate $=0,30 \overline{9}$ );

- присінково-язиковий розмір шийки нижнього лівого другого малого кутнього зуба (східний регіон) =

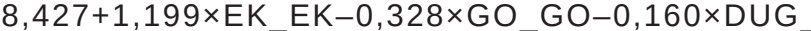
$\mathrm{AUAU}+0,079 \times \mathrm{N}^{-} \mathrm{PRN}-0,555 \times \mathrm{TR}^{-} \mathrm{N}-0,655 \times \mathrm{CHI}^{-}$ CHI+0,695 $\times$ MF_MF-0,146 $\times$ TIP_LICA $\left(R^{2}=0,559 ; F_{(4,12)}=5,26\right.$; $p<0,01$; Error of estimate $=0,66 \overline{6})$;

- мезіо-дистальний розмір шийки нижнього лівого другого малого кутнього зуба (східний регіон) = 11,23$0,367 \times Z M \quad Z M-0,139 \times$ DUGS GOP+0,531×RGO GN$0,217 \times Z Y \_Z Y+0,392 \times N \_I-0,240 \times T R \_N\left(R^{2}=0,505\right.$; $F_{(4,76)}=5,28 ; p<0,01$; Error of estimate $\left.=0,513\right)$;

- мезіо-дистальний розмір шийки нижнього правого першого малого кутнього зуба (східний регіон) = 11,04$0,136 \times Z M \_Z M-0,150 \times D U G S \_G O P+0,402 \times E K \_E K-$ $0,270 \times$ TR_N-0,329 $\times \mathrm{CHI}$ _CHI+0,137 $\times$ TIP_GOL$0,114 \times$ TIP_LICA $\left(R^{2}=0,569 ; F_{(5,10)}=7,27 ; p<0,001\right.$; Error of estimate $=0,361)$;

- присінково-язиковий розмір шийки нижнього правого другого малого кутнього зуба (східний регіон) =

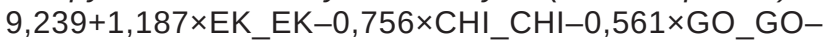
$0,094 \times$ DUG_AUAU $+0,054 \times$ N_PRN $-0,623 \times$ SN_PRN $\left(R^{2}=0,519 ; F_{(5,03)}=6,28 ; p<0,01 ;\right.$ Error of estimate $\left.=0,641\right)$;

- висота коронки нижнього правого другого малого кутнього зуба (східний регіон) $=20,49-1,164 \times \mathrm{AL}$ AL$0,396 \times$ TIP_LICA-0,141 NN_PRN+1,056 $\times$ MF_MF$0,230 \times$ DUG_GOP+0,572 $\times$ LGO_GN-0,184 $\times$ FMT_FMT $\left(R^{2}=0,603 ; F_{(5.85)}=7,27 ; p<0,001\right.$; Error of estimate=0,571); де AL_AL - ширина основи носа (cм); CHI_CHI - ширина ротової щілини (см); DUG_AUAU - поперечна дуга (см); DUG GOP - найбільший обххват голови (см); DUGS GOP - сагітальна дуга (см); EK_ЕК - зовнішньоочна ширина (см); EU_EU - найбільша ширина голови (см); FMT_FMT - найменша ширина голови (см); G_OP - найбільша довжина голови (см); GO_GO - ширина нижньої щелепи (см); LGO GN - довжина тіла нижньої щелепи зліва (см); MF_MF - міжочноямкова ширина (см); N_GN - морфологічна довжина обличчя (см); N_I - відстань між назіон та міжрізцевою точкою (см); N_PR N - довжина носа (см); N_SN - висота носа (см); N_STO - висота верхньої частини обличчя (см); RGO GN - довжина тіла нижньої щелепи справа (см); SN_PRN - глибина носа (см); TIP GOL - краніотип (1 - доліхоцесрали, 2 - мезоцесрали, $\overline{3}$ - брахіцесрали, 4 - гіпербрахіцесрали); TIP LICA - тип обличчя (1 - широке, 2 - середнє, 3 - вузьке, 4 - дуже вузьке); TR_GN - фрізіологічна довжина обличчя (см); TR_N - висота лоба (см); ZM_ZM - середня ширина обличчя (см); ZY_ZY - ширина обличчя (сM).

Моделі усіх інших лінійних розмірів малих кутніх зубів у практично здорових чоловіків різних регіонів України (в тому числі й центрального) мають коефріцієнт детермінації менше 0,5 і тому не мають суттєвого значення для практичної стоматології.

Таким чином, за допомогою регресійного аналізу на основі особливостей кефралометричних показників, краніотипу і типу обличчя ми побудовали достовірні моделі 
(із коефріцієнтом детермінації $\mathrm{R}^{2}$ більшим ніж 0,5) індивідуальних лінійних розмірів малих кутніх зубів верхньої і нижньої щелеп у практично здорових чоловіків північного (6 моделей мезіо-дистальних розмірів, $\mathrm{R}^{2}=0,562-0,715$; 4 моделі присінково-язикових розмірів, $\mathrm{R}^{2}=0,525-0,822$; 3 моделі висоти коронок, $\left.\mathrm{R}^{2}=0,507-0,632\right)$, південного (1 модель мезіо-дистальних розмірів, $\mathrm{R}^{2}=0,509 ; 3$ моделі висоти коронок, $\mathrm{R}^{2}=0,564-0,702$ ), західного (4 моделі мезіо-дистальних розмірів, $\mathrm{R}^{2}=0,535-0,659 ; 1$ модель висоти коронок, $\left.\mathrm{R}^{2}=0,522\right)$ і східного (6 моделей мезіодистальних розмірів, $\mathrm{R}^{2}=0,505-0,641 ; 2$ моделі присінково-язикових розмірів, $\mathrm{R}^{2}=0,519$ і 0,559; 1 модель висоти коронок, $R^{2}=0,603$ ) адміністративно-територіальних регіонів України. У більшості випадків, незалежно від регіону, моделі мезіо-дистальних розмірів коронки і шийки малих кутніх зубів побудовані для верхньої щелепи, а висоти коронок - для нижньої щелепи.

До побудованих моделей індивідуальних лінійних розмірів малих кутніх зубів верхньої і нижньої щелеп із коесріцієнтом детермінації більше 0,5 найчастіше входять:

- у чоловіків північного регіону України до моделей мезіо-дистальних розмірів - поперечна дуга і ширина ротової щілини (по 10,5 \%) та ширина основи носа, ширина нижньої щелепи і довжина тіла нижньої щелепи зліва (по 7,9 \%); до моделей присінково-язикових розмірів - висота верхньої частини обличчя (16,0 \%), найбільша довжина голови, довжина тіла нижньої щелепи зліва і морфологічна довжина обличчя (по 12,0 \%); до моделей висоти коронок - зовнішньоочна ширина $(18,7$ \%) та поперечна дуга і довжина тіла нижньої щелепи зліва (по $12,5 \%)$

\section{СПИСОК ЛІТЕРАТУРИ}

1. Алексеев В. П. Краниометрия: методика антропологических исследований / В. П. Алексеев, Г. Ф. Дебец. - М. : Наука, 1964. $-128 \mathrm{c}$.

2. Геометрически-грасрическая репродукция зубочелюстных дуг при сризиологической окклюзии постоянных зубов / Д. А. Доменюк, С. В Дмитриенко, Э. Г. Ведешина [ и др.] // Институт стоматологии. - 2015. - № 1. - С. 62-65.

3. Даньшина (Гордеева) Е. Г. Разработка продукционной модели дифференциации патологий зубочелюстной системы на основе расчета ортодонтических индексов соотношения зубных дуг / Е. Г. Даньшина (Гордеева), Е. Н. Коровин // Системный анализ и управление в биомедицинских системах. - 2013. - T. 12, № 3. - С. 704-711.

4. Зубов А. А. Одонтология. Методика антропологических исследований / А. А. Зубов. - М. : Наука, 1968. - 200 с.

5. Просрфит У. Р. Современная ортодонтия / У. Р. Просрфит ; пер. с англ. ; под ред. Л. С. Персина. - М. : Медпресс-инорорм., 2015. -560 c.
- у чоловіків південного регіону України до моделей висоти коронок - висота лоба (17,6\%), найбільший обхват голови, ширина основи носа, міжочноямкова ширина і довжина тіла нижньої щелепи справа (по 11,8 \%);

- у чоловіків західного регіону України до моделей мезіо-дистальних розмірів - найбільший обхват голови і відстань між назіон та міжрізцевою точкою (по 14,8 \%), поперечна дуга, ширина ротової щілини і довжина тіла нижньої щелепи справа (по 11,1 \%);

• у чоловіків східного регіону України до моделей мезіодистальних розмірів - сагітальна дуга, ширина ротової щілини і висота лоба (по 12,8 \%), середня ширина обличчя (10,3 \%) і довжина тіла нижньої щелепи зліва $(7,7 \%)$; до моделей присінково-язикових розмірів - поперечна дуга, ширина ротової щілини, зовнішньоочна ширина, ширина нижньої щелепи і довжина носа (по 14,3 \%).

Базові регресійні рівняння для різних регіонів України, які ми визначили, будуть спрямовані на усунення відповідних лікувально-діагностичних проблем у практичній стоматології і превентивній медицині.

ВИСНОВКИ 1. На основі особливостей кефралометричних показників та типу голови й обличчя у практично здорових чоловіків із різних адміністративно-територіальних регіонів України розроблено достовірні регресійні моделі (з коефіцієнтом детермінації $R^{2}$ більшим ніж 0,5) індивідуальних лінійних розмірів малих кутніх зубів верхньої і нижньої щелеп.

Перспективи подальших досліджень полягають у клінічній апробації отриманих результатів регресійного моделювання індивідуальних лінійних розмірів малих кутніх зубів у різних адміністративно-територіальних регіонах України.
6. Скринінг-оцінка впровадження здоров'ясрормуючих інновацій у загальноосвітніх навчальних закладах : навчально-методичний посібник / [Г.М.Даниленко, Л. Д. Покроєва, І.С.Кратенко та ін.]. - Харків, Харківський обласний науково-методичний інститут безперервної освіти, 2005. - 76 с.

7. Смердина Ю. Г. Этнические особенности одонтологических признаков / Ю. Г. Смердина, Л. Н. Смердина // Научный журнал "Успехи современного естествознания" : Изд-во "Российская Академия Естествознания", 2007. - № 8. - С. 63-64.

8. Evaluation of volumetric changes of teeth in a Brazilian population by using cone beam computed tomography / L. V. Porto, J. Celestino da Silva Neto, A. D. Anjos Pontual, R. Q. Catunda // J. Forensic Leg. Med.. - 2015. - No. 36. - P. 4-9.

9. Image quality produced by different cone-beam computed tomography settings / J. C. Kwong, J. M. Palomo, M. A. Landers [et al.] // Am. J. Orthod. Dentofacial. Orthop. - 2008. - No. 133. - P. 317-327.

10. Prevalence and morphometric analysis of three-rooted mandibular first molars in a Brazilian subpopulation / C. T. Rodrigues, C. Oliveira-Santos, N. Bernardineli [et al.] // J. Appl. Oral. Sci.. - 2016. - Vol. 24, No. 5. - P. 535-542. 


\section{MODELING USING REGRESSION ANALYSIS OF INDIVIDUAL LINEAR DIMENSIONS OF PREMOLARS DEPENDING ON CEPHALOMETRIC INDICATORS OF PRACTICALLY HEALTHY MEN FROM DIFFERENT REGIONS OF UKRAINE}

SUMMARY. According to the literature, the development of a variety of diagnostic models should be adapted to the use of specific regions within the range of the settlement of large ethnic groups of the population.

The aim of the study - to construct and analyze the regression models of individual linear sizes of small angular teeth depending on the cephalometric indices of practically healthy men from different administrative-territorial regions of Ukraine.

Materials and Metohods. 200 practically healthy men in the third generation residents of different administrative-territorial regions of Ukraine (northern region - 32 inhabitants from Zhytomyr, Kyiv, Chernihiv and Sumy regions; southern region - 33 inhabitants from Odesa, Mykolaiv, Kherson, Zaporizhzhia regions and the Autonomous Republic of Crimea; central region - 64 inhabitants from Vinnytsia, Cherkasy, Kirovohrad, Poltava and Dnipropetrovsk regions; western region - 36 inhabitants from Volyn, Rivne, Lviv, Chernivtsi, Ternopil, Khmelnytskyi, Transcarpathian and Ivano-Frankivsk regions; eastern region - 35 inhabitants from Kharkiv, Donetsk and Luhansk regions), a computer-tomographic study of small corner teeth with subsequent odontometry and cephalometry was conducted. The construction of regression models of individual linear dimensions of small corner teeth, depending on the cephalometric indices, was performed using the statistical software package "Statistica 6.1".

Results and Discussion. By using regression analysis based on the features of cephalometric indices, craniotype and face type we have built reliable models (with determination coefficient $\mathrm{R}^{2}$ greater than 0.5 ) of individual linear sizes of small angular teeth of the upper and lower jaws in practically healthy men of the northern (6 models of mesio-distal dimensions, $R^{2}=0.562-0.715 ; 4$ models of vestibular-lingual dimensions, $R^{2}=0.525-0.822 ; 3$ models of height of crowns, $\left.R^{2}=0.507-0.632\right)$, southern (1 model mesio-distal sizes, $R^{2}=$ $0.509 ; 3$ models heights of crowns, $R^{2}=0.564-0.702$ ), western ( 4 model mesio-distal sizes, $R^{2}=0.535-0.659 ; 1$ model height crowns, $\left.R^{2}=0.522\right)$ and eastern (6 models of mesio-distal dimensions, $R^{2}=0.505-0.641 ; 2$ models of vestibular-lingual sizes, $R^{2}=0.519$ and 0.559; 1 model of crown height, $\mathrm{R}^{2}=0.603$ ) administrative-territorial regions of Ukraine. In most cases, regardless of the region, models of mesio-distal dimensions of the crown and neck of small corner teeth are constructed for the upper jaw, and the height of the crowns - for the mandible.To constructed models of individual linear sizes of small angular teeth of the upper and lower jaws with a determination coefficient more than 0.5 most often include: in men of the northern region of Ukraine to models of mesio-distal dimensions - the transverse arc and the width of the mouth gap (by $10.5 \%$ ) and width base of the nose, width of the lower jaw and length of the body of the mandible on the left (by $7.9 \%$ ); to models of vestibular-lingual dimensions - the height of the upper part of the face (16.0\%), the largest length of the head, the length of the body of the mandible on the left and the morphological length of the face (by $12.0 \%$ ); to models of crown height - foreign eye width (18.7\%) and transverse arc and length of the body of the mandible on the left (by $12.5 \%)$; in men in the southern region of Ukraine to models of crown height - height of the forehead (17.6\%), the largest girth of the head, the width of the base of the nose, the intercostal width and the length of the body of the mandible on the right (by $11.8 \%$ ); in men of the western region of Ukraine to models of mesio-distal sizes - the largest head circumference and the distance between the nasion and the inter-cutter point (by $14.8 \%$ ), the transverse arc, the width of the mouth gap and the length of the body of the mandible on the right (by $11.1 \%$ ); in men of the eastern region of Ukraine to models of mesio-distal dimensions - sagittal arc, mouth width and forehead height (by $12.8 \%)$, mean facial width (10.3\%) and body length of the mandible on the left (7.7\%); to the models of vestibular-lingual dimensions - the transverse arc, the width of the mouth, the width of the mandible, and the length of the nose (by $14.3 \%$ ).

Conclusions. Based on the features of cephalometric indices and the type of head and face in practically healthy men from different administrative-territorial regions of Ukraine, reliable regression models (with determination coefficient $\mathrm{R}^{2}$ greater than 0.5 ) of individual linear sizes of small angular teeth of the upper and lower jaws have been developed.

Key words: premolars; linear dimensions; cephalometry; regression models; practically healthy men; administrative-territorial regions of Ukraine.

СВ. О. Орловскийㅁ, М. М. Шинкарук-Диковицкая ${ }^{1}$, И. В. Гунас ${ }^{2}$ Винницкий национальный медицинский университет имени Н. И. Пирогова ${ }^{1}$ Международная академия интегративной антропологии, г. Винница²

\section{МОДЕЛИРОВАНИЕ С ПОМОЩЬЮ РЕГРЕССИОННОГО АНАЛИЗА ИНДИВИДУАЛЬНЫХ ЛИНЕЙНЫХ РАЗМЕРОВ МАЛЫХ КОРЕННЫХ ЗУБОВ В ЗАВИСИМОСТИ ОТ КЕФАЛОМЕТРИЧЕСКИХ ПОКАЗАТЕЛЕЙ ПРАКТИЧЕСКИ ЗДОРОВЫХ МУЖЧИН ИЗ РАЗНЫХ РЕГИОНОВ УКРАИНЫ}

Резюме. Согласно литературным данным, разработка различных диагностических моделей должна быть адаптирована к населению конкретного региона.

Цель исследования - построить и провести анализ регрессионных моделей индивидуальных линейных размеров малых коренных зубов в зависимости от кефалометрических показателей практически здоровых мужчин из разных административнотерриториальных регионов Украины.

Материалы и методы. Проведено компьютерно-томографическое исследование малых коренных зубов с последующей одонтометрией и кесралометрией. 200 практически здоровым мужчинам- жителям разных административно-территориальных регионов Украины (северный регион - 32 жителя из Житомирской, Киевской, Черниговской и Сумской областей; южный регион - 33 жителя из Одесской, Николаевской, Херсонской, Запорожской областей и АР Крым; центральный регион - 64 жителя из Винницкой, Черкасской, Кировоградской, Полтавской и Днепропетровской областей; западный регион - 36 жителей из Волынской, Ровенской, Львовской, Черновицкой, Тернопольской, Хмельницкой, Закарпатской и Ивано-Франковской областей; восточный регион - 35 жителей из Харьковской, Донецкой и Луганской областей) Построение регрессионных моделей индивидуальных линейных размеров малых коренных зубов в зависимости от кефралометрических показателей проводили с помощью лицензионного статистического программного пакета Statistica 6.1. 
Результаты исследований и их обсуждение. С помощью регрессионного анализа на основе особенностей кефралометрических показателей, краниотипа и типа лица нами построены достоверные модели (с коэффрициентом детерминации $\mathrm{R}^{2}$ больше чем 0,5) индивидуальных линейных размеров малых коренных зубов верхней и нижней челюстей у практически здоровых мужчин северного, южного, западного и восточного административно-территориальных регионов Украины. В большинстве случаев, независимо от региона, модели мезио-дистальных размеров коронки и шейки малых коренных зубов построены для верхней челюсти, а высоты коронок - для нижней челюсти. К построенным моделям индивидуальных линейных размеров малых коренных зубов верхней и нижней челюстей с коэффициентом детерминации более 0,5 зачастую входят: у мужчин северного региона Украины к моделям мезио-дистальных размеров - поперечная дуга и ширина ротовой щели (по $10,5 \%$ и и ширина основания носа, ширина нижней челюсти и длина тела нижней челюсти слева (по 7,9 \%); к моделям преддверно-языковых размеров - высота верхней части лица (16,0 \%), наибольшая длина головы, длина тела нижней челюсти слева и морфологическая длина лица (по 12,0 \%); к моделям высоты коронок - внешне глазная ширина (18,7 \%) и поперечная дуга и длина тела нижней челюсти слева (по 12,5 \%); у мужчин южного региона Украины к моделям высоты коронок - высота лба (17,6 \%), наибольший обхват головы, ширина основания носа, межглазничная ширина и длина тела нижней челюсти справа (по 11,8 \%); у мужчин западного региона Украины к моделям мезио-дистальных размеров - самый большой обхват головы и расстояние между назион и межрезцовой точкой (по 14,8 \%), поперечная дуга, ширина ротовой щели и длина тела нижней челюсти справа (по 11,1 \%); у мужчин восточного региона Украины к моделям мезио-дистальных размеров - сагиттальная дуга, ширина ротовой щели и высота лба (по 12,8 \%), средняя ширина лица (10,3 \%) и длина тела нижней челюсти слева (7,7 \%); к моделям преддверно-языковых размеров - поперечная дуга, ширина ротовой щели, внешнеглазная ширина, ширина нижней челюсти и длина носа (по 14,3 \%).

Выводы. На основе особенностей кефралометрических показателей и типа головы и лица у практически здоровых мужчин из разных административно-территориальных регионов Украины разработаны достоверные регрессионные модели (с коэсрфициентом детерминации $\mathrm{R}^{2}$ больше чем 0,5$)$ индивидуальных линейных размеров малых коренных зубов верхней и нижней челюстей.

Ключевые слова: малые коренные зубы; линейные размеры; кефралометрия; регрессионные модели; практически здоровые мужчины; административно-территориальные регионы Украины. 